\title{
Test Technique as a Tool for Evaluation of Learning Outcomes
}

\author{
Ulfi Hayati ${ }^{1}$, Muhammad Ediyani ${ }^{2}$, Maimun $^{3}$, Kasyful Anwar ${ }^{4}$, M. Bahriza Fauzi ${ }^{5}$, \\ Suryati6 $^{6}$ \\ 1,2,3,4,5,6 STIT Syamsuddhuha Aceh Utara, Indonesia \\ ediyani03@gmail.com
}

\begin{abstract}
In the world of education to find out whether the educational process is successful in accordance with educational goals, it is necessary to conduct an evaluation to find out the extent of its success. Measuring is the most common activity carried out and is an action that initiates evaluation activities in the assessment of learning outcomes. The test is a method used by educators to measure and assess students' abilities systematically, fairly, objectively, and prosuderal by giving tasks in the form of questions and statements that must be done by students so that they can produce values that symbolize student achievement.
\end{abstract}

Keywords

test technique; evaluation of learning outcomes

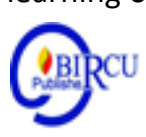

\section{Introduction}

One of the efforts of national development in the field of education is to educate the life of the nation and improve the quality of Indonesian people who believe, have faith and have noble character and master science, technology, and art in realizing an advanced, just, prosperous, and civilized society based on Pancasila and the Law Basic State of the Republic of Indonesia in 1945.

In the world of education to find out whether the educational process is successful in accordance with educational goals, it is necessary to conduct an evaluation to find out the extent of its success. Measuring is the most common activity carried out and is an action that initiates evaluation activities in the assessment of learning outcomes.

The evaluation technique is also called an instrument or data collection tool. Learning outcomes are not only contained in the form of tests with various forms or variations, but there are still other techniques that can be used, namely non-test techniques.

Therefore, the authors in this article want to explain about test techniques as an evaluation tool for learning outcomes as a contribution to developing science and educators able to understand and know about learning evaluation techniques.

\section{Review of Literature}

\subsection{The Definition of Test}

Literally, the word "test" comes from Old French, which is "testum" with the meaning: "a plate used to set aside or choose precious metals from other objects", such as sand, stone, earth, and so on. Whereas in English written with a test in Indonesian translated with "tes", "test" or "trial". In Arabic: Imtihan (إمتحان).

The terminology test as revealed by Anne Anastasi in her paper titled Psychological Testing as quoted by Anas Sudjiono is a measuring tool that has objective standards so that it can be used extensively, and can actually be used to measure and compare psychic or behavioral conditions individual. While Lee J. Cronbach in his book titled Essential of 
Psychological Testing announced that the test is a systematic procedure for comparing the behavior of two or more people. While according to Goodenough, the test is a task or series of tasks given to individuals or groups of individuals, with a view to comparing their skills, one with another.

Through learning the text of observational reports, students can learn the universe and the surrounding environment. This learning can help students to recognize themselves an their environment (Wahyuni, 2019). Sax defines the test as quoted by Mawardi Lubis as a task or set of tasks used to obtain systematic feedback that is considered to reflect trait or educational or psychological attributes. According to Musdiani (2019) the purpose of Education is to direct the growing potential of learners to be a man of pious care to the One God Almighty, qualified, possessed of sublime pekerti ability and virtuousness. Education has a very strategic role in determining the direction of the forthcoming of the nation's quality of community knowledge. Furthermore that Sax also stressed that the test, containing tasks arranged to produce systematic observations about a trait.

Zainal Arifin defines the test of a technique or method used in carrying out measurement activities, in which there are various questions, statements, or series of tasks that must be done or answered by students to measure aspects of student behavior.

Based on the brief description above, what is meant by the test is a method used by educators to measure and assess students' abilities systematically, fairly, objectively, and prosuderal by giving assignments in the form of questions or statements that must be done by students so that they can produce values that symbolize student achievement.

\subsection{The Function of Test}

The test functions in education can be categorized as follows:

1. As a measure tool against students. In this connection the test serves to measure the level of development or progress that has been achieved by students after they take the teaching and learning process within a certain period.

2. As a measure tool of the success of teaching programs, because through these tests will be known how far the teaching programs that have been determined, can be achieved.

3. As a tool for determining the placement of students in a certain level or type of educational program (placement test).

4. As a tool for seeking feedback to improve the teaching-learning process for teachers and students (formative test).

5. As a tool for seeking causes of student learning difficulties, such as psychological, physical, and socio-economic backgrounds of students.

\section{Discussion}

\subsection{Distribution Test}

Tests as an evaluation tool can be divided into verbal and non-verbal tests. Verbal tests are tests that use language (phrases of words or sentences) as a tool to carry out tests, verbal tests consist of oral tests and written tests. While non-verbal tests are tests that do not use language (word expressions or sentences) as a tool to carry out tests, but use certain actions or called acts tests.

\section{a. Written Test}

Written test (pencil and paper test), which is a test where the tester in asking questions is done in writing and the testee gives answers also in writing. In writing scientific papers, 
technicallythe language needs to be considered when writing direct or indirect quotations, writing reference lists, writing words, writing abbreviations, writing punctuation marks, using sentences, especially reasoning sentences (Sitepu, 2019). The written test can be categorized into two types namely objective tests and subjective tests (description).

1. Objective Test

An objective form test is a test in which all the information needed to answer the test is available and the item contains possible answers that must be selected or worked on by the test taker.

Suharsimi also stated that an objective test is a test in which the examination can be carried out objectively. This is indeed intended to overcome the weaknesses of the essay test form. In using this objective test the number of questions asked is far more than the essay test.

The above understanding is almost in line with Zainal's statement which reveals that objective tests require test takers to choose the correct answer among the possible answers provided, give short answers, and complete imperfect statements.

The conclusion that can be drawn from the statements above is that an objective test is a type of learning achievement test consisting of several questions that can be answered by choosing, pairing, and filling in the answers. Objective test questions are useful for measuring low-level cognitive learning outcomes, complex learning outcomes such as creating and organizing ideas are not suitable to be measured by this form of test.

The following are included advantages, disadvantages and ways to overcome the weaknesses of objective tests:

1). Strengthnesses

a. More objective and broad material. It can be avoided the interference of subjective elements both from the test takers and the examining teacher.

b. High reliability and validity

c. Easier and faster way to check it

d. The examination can be left to someone else

2). Weaknesses

a. Does not measure higher mental processes

b. Preparing to compile it is far more difficult than an essay test because there are many questions to be investigated to avoid other weaknesses.

c. The questions tend to express memories and recollections only, and it is difficult to measure high mental processes

d. Many opportunities to play luck

e. Cooperation between test participants when working on tests is more open

3). How to Overcome

a. The difficulty of compiling objective tests can be overcome by practicing constantly until they are truly proficient

b. Using norms (standards) that take into account guessing factor (guessing) that is speculative.

Objective tests can be classified into the following forms:

a. True-False Test

The questions are in the form of statements. The statement is true and false. The test taker who was asked was tasked with marking each statement by circling the letter B if the statement was true in his opinion and circling the letter $\mathrm{S}$ if the statement was wrong.

This test is of two kinds, namely with correction, and without correction. The following are suggestions for making this test: 
a) Try to keep the number of questions to be answered B the same as the number of questions to be answered S. In this case the answer pattern should not be regular, for example: BSBS or SSBB

b) Avoid debatable statements. For example: B / S Wealth is more important than intelligence

c) Avoid questions that are exactly in the textbook. Example: B - S Prayer is one of the pillars of Islam

\section{b. Multiple Choice Test}

Multiple Choice Test consists of a statement or notification about an incomplete understanding. To complete it must choose one of several possible answers that have been provided. Or the Multiple Choice Test consists of an information section (stem) and a possible answer or alternative (options) section. Possible answers consist of one correct answer, which is the answer key and several distractors. As for things that need to be considered in a multiple choice test

a) The operating instructions must be clear and, if deemed necessary, be accompanied by examples of working on them

b) The correct answer is only one. So do not recognize the levels of true for example true number one, true number two and so on.

c) The answers are arranged downward not sideways to facilitate test takers

d) Avoid using sentence structures in textbooks. Because what was revealed might not be his understanding but his memorization.

\section{c. Matching Test}

Matching Test consists of a series of questions and one series of answers. Each question has an answer listed in the answer series. The student's task is to find and place answers so that they fit the question. The thing to note in the preparation of this test is that the number of answers that must be chosen must be more than the number of questions. Thus test takers are faced with many choices so that test takers use their minds more.

\section{d. Completion Test / Fill in Test}

There are some references that distinguish the completion test with the test content (fill in test) and there are also some that make them both in one discussion item (liken it). The speaker refers more to the equalizer because the basic principle of this test is to refine the statement that was omitted. However, speakers can grasp the understanding that the difference between the two lies in the material used as a test. If the fill-in test the material being tested is the unity of the story, the completion test does not have to be.

Continuing the discussion on unifying the terms of the filling and completing tests, Suharsimi revealed that the Completion Test is commonly referred to as the filling test, completing test, or completing test. Completion Test consists of sentences that have parts removed. The omitted portion or part that must be filled in by the test taker is the understanding requested from the test taker.

Even according to Sukardi the filling / completing test has many similarities, especially in three ways. First, it requires memorization. Second, demanding a short answer. Third, the test is planned to reveal students' thoughts about learning material that is categorized as a definition or boundary, knowledge of facts, and principles of knowledge.

Suggestions in preparing this test are as follows:

a) Do not quote the sentence listed in the textbook

b) Don't start sentences with blank spaces 


\section{Subjective Test (Description)}

Subjective test is one type of learning test that has the following characteristics

a) The test is in the form of a question or order that requires an answer in the form of a description or exposure to the sentence.

b) The forms of questions require testees to provide explanations, comments, and interpretations.

c) The number of items is limited, which ranges from five to ten questions.

d) In general, the test items of the description begins with the words "explain, describe, why, how, and other words similar to them.

The development of descriptive test forms can be used to measure learning activities that are difficult to measure by objective forms. The description form test is also called subjective assessment because it is often also influenced by the subjectivity of the teacher. Judging from the breadth and breadth of the material in question can be divided into:

1) Limited Description

Students in answering questions must state certain things as the limit. Even though the sentences of the students' answers are various but there must still be important points contained in the mathematical system of answers in accordance with the limits specified and desired in the problem.

2) Free Description

Students are free to answer questions in a way and systematically themselves and are free to express opinions in accordance with their abilities. However, the teacher must have a benchmark in correcting.

\section{b. Oral Test}

Oral test (non-remote and paper test), which is a test where the tester in asking questions is done verbally, and the testee gives answers verbally as well. Thus, an oral test is a form of test that demands responses from students in the form of spoken language. Students will say the answer in their own words in accordance with the questions or instructions given.

Provisions to be followed in an oral test are as follows:

1) The degree of difficulty, the content of knowledge, the amount of time provided and the maximum number that might be achieved by each test taker should be estimated to be the same

2) If the test taker still cannot give an answer until the allotted time runs out it should move to the next test number

3) In reading the test the examiner may use the examiner's own words as long as the essence is the same

4) Examiners are prohibited from strafing or rubbing with follow-up questions which are apparently not written on the test sheet

5) Give numbers solely based on the quality of the test taker's answers.

\section{c. Deed Test}

The act test is a form of test that demands students' answers in the form of behavior, actions or deeds. Students act according to what is ordered and asked. For example, try to practice how to ride a motorcycle properly and correctly, to see how to ride a motorcycle properly, we must ask children to practice or demonstrate how to ride a motorcycle in accordance with applicable regulations.

Act tests can be classified into three forms as follows:

1) Identification tests, including the depth of variation in test situations that represent varying degrees of field reality. Generally this is done in the 'education / industrial institution' 
field. For example, identification of the task performance section (eg finding a 'short circuit' on an electricity network) he will identify: the tools, equipment and procedures needed to handle the task. Another example in the practice of Arabic, as a participant in the Arabic debate contest with the theme of democratic politics, the tool prepared is to increase the vocabulary associated with politics. In general the identification test is used as a teaching tool / strategy to prepare students' actual performance in simulated and actual situations.

2) Simulation, more emphasis on procedures, namely how students can display the same behavior (an assignment) in real situations as displayed in the simulation. For example: demonstrating 'swimming' with certain styles and techniques, simulating interviews between instructors (companies) and job applicants for a job. This is used in teaching to evaluate goals. In some situations, student performance simulations are used as a final assessment of a particular skill (eg chemistry laboratory performance, driving training). In Arabic practice can simulate buying and selling at the time of Hajj, where students must interact with native speakers, namely by using the Arabic 'amiyah with the same behavior in real situations.

3) Work sample, this is the highest level of 'realization'. Here requires students to display the actual task that represents the overall performance to be measured. Includes crucial elements and controlled appearance with certain standards. Each student's performance on a standard is then used as evidence of an individual's ability (regarding an assignment) in a particular condition. Examples in the industrial field, for example, students are required to complete a project from metalworker work or woodworking which involves all stages as in the actual work situation (determining, selecting / sorting materials, and constructing).

The provisions that need to be considered in carrying out an action test are as follows

1) Observations should be made in such a way that they are not like watching.

2) Recording should be done immediately after an action has been completed by the test taker.

3) Examiners should not prohibit or give suggestions to test takers who make mistakes.

4) Give numbers solely based on the quality and process of the test taker.

As a measuring device, the test can also be divided into several types or classes, depending on which aspects or for what reasons the classification of the test is carried out.

1. Classification of tests based on their function as a gauge of the development or progress of learning of students, divided into six groups, namely:

a) Selection tests (al-Imtihan al-Intikhabiy = الإمتحان الإنتخابى), often known as the "Sieve Test" or "Entrance Examination". This test is carried out in the context of acceptance of prospective new students, where the test results are used to select prospective students who are classified as the best of the many candidates who take the test. The selection test can be carried out verbally, in writing, with an action test, and can also be carried out by combining all three types of tests simultaneously.

b) Initial tests (al-Imtihan al-Mabda'iy = الإمتحان المبدئى), often known as pre-test. This test is carried out with the aim to find out to what extent the material or subject matter to be taught has been mastered by the students. The content or initial test material is generally emphasized on important materials that should have been known or mastered by students before the lesson is given to them.

c) Final test (al-Imtihan al-Niha'iy = الإمتحان النهائى), often known as the post-test. This test is carried out with the aim to find out whether all the subject matter that is classified as important can be mastered properly by the students. The contents or material of the final test are classified as important learning materials, which have been taught to students, and usually the final test script is made the same as the initial test script. 
d) Diagnostic test (al-Imtihan al-Fahshiy = الإمتحان الفحصى). This test is carried out to determine precisely the types of difficulties faced by students in a particular subject. The material asked in diagnostic tests is generally emphasized on certain materials which are usually difficult for students to understand. This test can be carried out verbally, in writing, in action or a combination of the three.

e) Formative tests (al-Imtihan al-Yaumiy = ةالإمتحان اليوم), often known as "Daily Deuteronomy". This test is a learning achievement test that aims to find out to what extent students have been "formed" (in accordance with predetermined teaching goals) after they have followed the learning process within a certain period of time. This formative test is usually carried out in the middle of the course of a teaching program, which is carried out each time a unit of study or sub-topic ends or can be completed. This test material is generally emphasized on the lesson material that has been taught, both in the easy category and in the difficult category.

f) Summative tests (al-Imtihan al-Nisf al-Sanawiy = السنوي الإمتحان النصف)), often known as "General Repeat" or "Final Evaluation of Learning (EBTA)". This test is a test of learning outcomes that is carried out after a set of teaching units has been completed. Summative tests are conducted in writing, so that all students get the same questions. The purpose of this test is to determine the value that symbolizes the success of students after they take the learning process within a certain period.

2. Classification of tests based on psychological aspects that want to be revealed, divided into five groups, namely:

a) Intelligence test, which is a test carried out to reveal or know the level of intelligence of a person.

b) Ability test, which is a test carried out to reveal the basic abilities or special talents possessed by the testee.

c) Attitude test, which is a test carried out to reveal a person's predisposition or tendency to make a certain response to the world around him, either in the form of individuals or certain objects.

d) Personality test, which is a test that is carried out to reveal the characteristics of a person who many at least outwardly.

e) Learning achievement test, which is a test carried out to reveal the level of learning achievement.

3. Classifying the test based on the object being tested:

a) Individual test, which is a test which in its implementation requires a long time (for the same time the examiner can only test a candidate).

b) Group test, which is a test conducted on several students at the same time.

4. Classifying the test based on the time allotted for the teste to complete the test.

a) Power test, which is a test in which the time provided for the test to complete the test is not limited.

b) Speed test, which is a test in which the time available for the testee to complete the test is limited. 


\section{Conclusion}

Evaluation techniques are also called instruments or data collection tools, learning outcomes are not only contained in the form of tests with various forms or variations, but there are still other techniques that can be used, namely non-test techniques.

The test is a measurement tool in the form of questions, commands, and instructions that are shown to the testee to get a response according to the instructions. On the basis of the response, the level of chord in the quantitative form is determined, then compared to the predetermined standard for quantitative conclusions.

\section{References}

Arifin, Zainal, Evaluasi Instruksional, Bandung: Remaja Rosdakarya, 1991. , Evaluasi Pembelajaran, Bandung: Remaja Rosdakarya, 2012.

Arikunto, Suharsimi, Dasar-dasar Evaluasi Pendidikan, Jakarta: Bumi Aksara, 2012.

Basrowi, Evaluasi Belajar Berbasis Kinerja, Bandung: Karya Putra Darwati, 2012.

Farida Yusuf Tayibnapis, Evaluasi Program dan Instrumen Evaluasi, Jakarta: Asdi Mahasatya, 2008.

Hamid, Abdul, Mengukur kemampuan bahasa Arab Untuk Studi Islam, Malang: UIN Maliki Press, 2010.

Harijanto, Mohammad Konstruksi Tes sebagai Alat Ukur Hasil Belajar di Sekolah Dasar, Jurnal Kependidikan Interaksi,2 (2) Juni 2006.

Lubis, Mawardi, Evaluasi Pendidikan Nilai, Yogyakarta: Pustaka Pelajar, 2008.

Mulyadi, Evaluasi Pendidikan, Malang: UIN-Maliki Pers, 2010.

Musdiani, et al. (2019). Analysis the Role of Headmaster in Applying Quality of Education in Primary School Districts, Aceh Barat. Budapest International Research and Critics in Linguistics and Education (BirLE) Journal, 27-35.

Purwanto, Ngalim, Prinsip-Prinsip dan Teknik Evaluasi Pengajaran, Bandung: Remaja Rosdakarya, 1988.

Sitepu, T. (2019). Cooperative Model in Language Reasoning: Indonesian Language Teaching Materials in Teacher Training and Education Faculty of Muhammadiyah Sumatera Utara University. Britain International of Linguistics, Arts and Education (BIoLAE) Journal, 51-59.

Sudaryono, Dasar-Dasar Evaluasi Pembelajaran, Yogyakarta: Graha Ilmu, 2012.

Sukardi, Evaluasi Pendidikan, Jakarta: Bumi Aksara, 2008.

Sudjana, Djudju, Evaluasi Program Pendidikan Luar Sekolah; untuk Pendidikan Non Formal dan Pengembangan Sumber Daya Manusia, Bandung: Remaja Rosdakarya,2006.

Sudijono, Anas, Pengantar Evaluasi Pendidikan, Jakarta: Rajawali Pers, 2011.

Wahyuni, D., et al. (2019). Development of Attitude Assessment Instruments on Learning Text Report Observation Results for 7th Grade Students Smp Swasta Taman Harapan Medan. Budapest International Research and Critics Institute-Journal (BIRCI-Journal), 506-513. 